\title{
Pentingnya Keselamatan Dan Kesehatan Kerja (K3) Pada Site Proyek Konstruksi Di Era Pandemi Covid-19
}

\author{
The Importance Of Occupational Safety And Health In The Construction \\ Project Site In The Era Pandemic Covid-19
}

\author{
Amanda Ristriana Pattisinai ${ }^{1}$, Fitri Rohmah Widayanti ${ }^{2}$, Danayanti Azmi Dewi \\ Nusantara $^{3}$, Feriza Nadiar ${ }^{4}$ \\ 1,2,3,4 Jurusan Teknik Sipil, Fakultas Teknik, Universitas Negeri Surabaya, Jln. Ketintang Surabaya. Email: \\ amandaristriana@unesa.ac.id
}

\begin{abstract}
Abstrak
Di Indonesia, kemampuan masyarakat memahami bagaimana penanganan pandemi Covid-19 dinilai sangat rendah. Konsep keselamatan dan kesehatan kerja (K3) yang merupakan salah satu aspek perlindungan ketenagakerjaan dan merupakan hak dasar dari setiap tenaga kerja sering kali diabaikan oleh perusahaan konstruksi. Berdasarkan hasil riset pada pekerja konstruksi, tingkat pendidikan pekerja konstr uksi di Surabaya tergolong rendah sehingga sosialisasi dan edukasi dari pihak perusahaan merupakan kunci utama dislipin K3 dilakukan dalam kegiatan bekerja dalam kondisi wabah Covid-19 ini. Siapapun yang masuk dalam kategori berikut, tidak diizinkan masuk site konstruksi, antara lain bila ada anggota keluarga atau kerabat dekat yang sedang karantina atau positif Covid-19, menunjukkan satu atau lebih gejala Covid-19, dan orang yang rentan (faktor usia, kondisi klinis, hamil). Alat Pelindung Diri (APD) yang harus digunakan dalam site konstruksi antara lain masker, sarung tangan, pelindung mata, wearpack, safety footwear dan helm proyek. Peraturanperaturan yang harus dipatuhi ketika pekerja memasuki dan memulai bekerja di site meliputi tiga tahapan yaiy ketika akan memasuki site proyek, ketika di dalam site proyek, dan k etika meninggalkan site proyek.
\end{abstract}

Kata Kunci: K3; Covid-19; Site Konstruksi

\begin{abstract}
In Indonesia, the public's ability to understand how to handle the Covid-19 pandemic is considered very low. The concept of occupational safety and health (K3), which is one aspect of labor protection and is the fundamental right of every worker, is often ignored by construction companies. Based on the research results on construction workers, the education level of construction workers in Surabaya is classified as low, so that socialization and education from the company is the primary key to K3 discipline carried out in working activities in the conditions of the Covid-19 outbreak. Anyone who falls into the following categories is not allowed to enter the construction site, including if a family member or close relative is quarantine or positive for Covid-19, shows one or more symptoms of Covid-19, and is a vulnerable person (age factor, clinical condition), pregnant). Personal protective equipment (PPE) that must use in construction sites include masks, gloves, eye protection, wear packs, safety footwear, and project helmets. The rules that must obey when workers enter and start working on the site include three stages: when entering the project site, while on the project site, and when leaving the project site.
\end{abstract}

Keywords: Occupational safety and health; Covid-19; Construction Site

\section{Pendahuluan}

Pandemi Covid-19 telah melemahkan berbagai sektor di Indonesia, tidak terkecuali sektor konstruksi. Pembatasan interaksi sosial dan perkumpulan manusia di tempat umum membuat berbagai pekerjaan termasuk pekerjaan konstruksi berhenti dan tertunda sementara. Berbagai kebijakan dan perubahan harus dilakukan agar sektor konstruksi tetap berjalan, mengingat perannya yang penting untuk menggerakkan perekonomian negara (Brawijaya, 2020).

Kementerian PUPR mengeluarkan Instruksi Menteri PUPR No 02 Tahun 2020 Tentang Protokol Proteksi/Desember 2020 Volume 2 No. 2 
Pencegahan Penyebaran Corona Virus Disease 2019 (Covid-19) dalam penye lenggaraan Jasa Konstruksi yang ditandatangani pada 27 Maret 2020. Hal ini merupakan langkah awal untuk memberikan perlindungan terhadap penyelenggaraan jasa konstruksi yang tengah berlangsung. Agar tetap menjamin kualitas para tenaga kerja konstruksi di tengah masa pandemi Direktur Jenderal Bina Konstruksi mengeluarkan Surat Edaran Direktur Jenderal Bina Konstruksi Nomor 17/SE/Dk/2020 tentang Pedoman Pembinaan Kompetensi Tenaga Kerja Konstruksi Dalam Periode Normal Baru. Pembinaan kompetensi harus tetap berjalan di tengah masa pandemi dengan tetap memperhatikan protokol kesehatan dan meminimalisir potensi penularan Covid-19. Sementara itu berbeda dengan kebijakan yang diterapkan di Indonesia, Kota Boston di Amerika Serikat menjadi kota metropolitan pertama di Amerika yang menghentikan seluruh pekerjaan konstruksi pada tanggal 18 Maret 2020. Meskipun demikian, masih terdapat beberapa pekerjaan konstruksi yang vital seperti pembangunan fasilitas publik, dan perbaikan utilitas kota yang tetap berjalan.

Mengenaskannya, setidaknya 100 proyek komersial di Jawa Timur terpaksa dihentikan sementara akibat penyebaran/wabah virus Covid-19. Meski proyek komersil terganggu, tetapi sektor konstruksi masih bisa mengandalkan segmen perumahan atau residensial yang masih mampu berjalan karena ada kebutuhan hunian masyarakat. Jumlah proyek residensial di Jatim yang masih dapat dilanjutkan ditengah wabah Covid-19 sepanjang kuartal I/2020 ini sebanyak 107 proyek dengan nilai mencapai US\$305,77 juta. Dari jumlah tersebut, kontribusi segmen real estate sekitar 60 persen, apartemen atau high rise 20 persen dan personal house 20 persen (https://surabaya.bisnis.com/read/20200408/532/12 24495/100-proyek-konstruksi-jatim-dihentikan diakses tanggal 19 April 2020).

Ketua Asosiasi kontraktor di Amerika Serikat (Associated General Contractors of America) berpendapat sebaliknya, penghentian pekerjaan konstruksi tidak akan banyak membantu melindungi kesehatan pekerja konstruksi karena seluruh pekerja telah menggunakan alat pelindung diri (APD) memadai untuk mencegah penyebaran virus Covid19. Bahkan menurutnya, penghentian tersebut akan sangat merugikan mereka karena menjadi tidak memiliki upah untuk kehidupan sehari-harinya (Hilda, 2018).

Namun menurut Lazuardi (2020), hal itu hanya merupakan wacana di negara maju lain. Di Indonesia sendiri kemampuan masyarakat memahami bagaimana penanganan pandemi Covid19 dinilai sangat rendah. Konsep keselamatan dan kesehatan kerja (K3) yang merupakan salah satu aspek perlindungan ketenagakerjaan dan merupakan hak dasar dari setiap tenaga kerja sering kali diabaikan oleh perusahaan konstruksi (Endriastuty dan Adawia, 2018).

Berdasarkan hasil riset pada pekerja konstruksi, tingkat pendidikan pekerja konstr uksi di Surabaya tergolong rendah (Helda dalam Fariz, 2014), yaitu tidak sekolah 38\%, lulusan SD 26\%, Lulusan SMP $29 \%$, dan sisanya merupakan lulusan SMA 9\%. Pendidikan pekerja konstruksi memang penting dalam meningkatkan kesadaran akan arti pentingnya kesehatandan keselamatan kerja (Mallapiang, 2017), namun demikian sosialisasi dan edukasi dari pihak perusahaan merupakan kunci utama dis lipin K3 dilakukan dalam kegiatan bekerja dalam kondisi wabah Covid-19 ini. Adapun inti kegiatan dalam PKM ini adalah memberikan bantuan sosialisasi pada Perusahaan Konstruksi (Kontraktor) terkait dengan protokol K3 versi pencegahan Covid 19. Mengingat semakin meluasnya korban Covid 19 , maka edukasi K3 terkait pencegahan wabah COVID-19 sangat urgent untuk dilakukan yang dikususkan bagi pekerja yang masih bekerja di Site pada perusahaan konstruksi yang belum melakukan sosialisasi K3 sehingga terhindar dari penularan virus tersebut. Diharapkan dengan adanya edukasi terkait protokol K3 versi pencegahan Covid 19 ini, pekerja mendapatkan pemahaman untuk mencegah penularan dan dapat dengan tenang melakukan pekerjaannya tanpa hambatan apapun terkait dengan keselamatannya.

\section{METODE}

Sebagai upaya peningkatan pengetahuan pentingnya K3 pada site proyek konstruksi di era pandemi COVID-19 di perusahaan konstruksi dalam hal ini kontraktor, Tim PKM Jurusan Teknik Sipil FT Unesa, merencanakan pelaksanaan penyuluhan berdasarakan pengetahuan dan peralatan yang dimiliki oleh Tim PKM Jurusan Teknik Sipil FT Unesa. Kegiatan tersebut dimaksudkan memberi pengetahuan kepada para pekerja di dunia proyek konstruksi tentang pentingnya K3 pada site proyek konstruksi di era pandemi COVID-19, guna meminimalisir terjadinya infeksi pada area site proyek konstruksi. Target Tim PKM Teknik Sipil FT Unesa adalah untuk meningkatkan pemahaman akan pentingnya $\mathrm{K} 3$ pada site proyek konstruksi di era pandemi COVID-19. Luaran yang diinginkan adalah setelah kegiatan,

1. Para kontraktor dan para pekerja site proyek konstruksi dapat memahami akan pentingnya K3 
pada site proyek konstruksi di era pandemi COVID-19.

2. Hasil kegiatan, para kontraktor dan para pekerja site proyek konstruksi dapat menerapkan K3 dengan standar tambahan di era pandemi COVID-19.

3. Para kontraktor dan para pekerja site proyek konstruksi setelah mengikuti koordinasi dengan tim PKM dapat meminimalisir penyebaran infeksi COVID-19 terjadi pada area site proyek konstruksi.

4. Para kontraktor dan para pekerja site proyek konstruksi mendapatkan draft pedoman K3 dengan standar tambahan di era pandemi COVID-19 bencana berupa power point yang dibagikan sebelum kegiatan dilaksanakan, sebagai bekal pemahaman untuk para kontraktor dan para pekerja site proyek konstruksi.

\section{HASIL DAN PEMBAHASAN}

Covid 19 dan Resiko Paparan di Site Konstruksi Corona virus merupakan keluarga besar virus yang menyebabkan penyakit ringan sampai berat, seperti atau pilek dan penyakit yang serius seperti MERS dan SARS-Penularannya dari hewan ke manusia (zoonosis) dan penularan dari manusia ke manusia sangat terbatas. Seperti apa tanda-tanda virus ini, gejalanya? Gejalanya demam lebih dari $38^{\circ} \mathrm{C}$, batuk, sesak napas yang membutuhkan perawatan di Rumah Sakit. Gejala ini diperberat jika penderita adalah usia lanjut dan mempunyai penyakit penyerta lainnya, seperti penyakit paru obstruktif menahun atau penyakit jantung.

Dampak yang ditimbulkan akibat virus corona?Untuk 2019-nCoV, dari kasus-kasus yang ditemukan saat ini, dampaknya tidak terlalu besar dan angka kematiannya kecil (hingga tanggal 19 Januari 2020 terjadi 2 kematian dari 198 kasus yang dilaporkan di Wuhan). Hingga saat ini WHO belum memberlakukan travel restriction untuk Wuhan. Namun demikian tetap harus diwaspadai karena sumber penularan dan perkembangan virus ini masih belumjelas-Berbeda dengan MERS dan SARS yang juga disebabkan oleh corona virus, dimana kedua penyakit ini mempunyai dampak yang sangat besar baik dalam sektor kesehatan maupun sosial ekonomi dunia.

Kelompok orang yang rentan terhadap virus corona dibagi menjadi 6 kelompok yaitu petugas kesehatan, orang yang serumah dengan penderita, orang yang bepergian dalam satu alat angkut, orang yang merawat atau menunggui pasien corona, tamu yang berdekatan dengan penderita dan orang yang bekerja sama dengan orang bervirus corona . Dari 6 kelompok yang rentan terhadap virus corona, 3 diantaranya berpotensi terdapat dan bisa terjadi di tempat kerja terlebih di site konstruksi yang dijelaskan pada gambar 1 berikut ini.

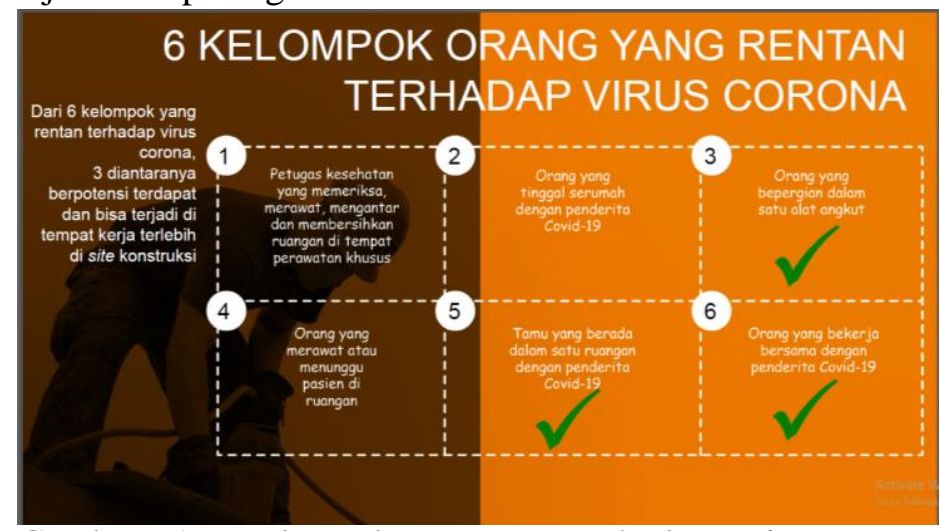

Gambar 1. Kelompok Rentan Terhadap Virus Corona.

Untuk beberapa department, seperti misal support staff, apabila memungkinkan untuk bekerja dari rumah, maka harus diprioritaskan untuk bekerja dari rumah. Tentukan bagian dan siapa saja yang benarbenar dibutuhan di site proyek. Mempertimbangkan siapa saja yang dibutuhkan di site proyek

Penempatan dan pengelompokan orang dalam jumlah besar sangat tidak disarankan karena semakin meningkatkan interaksi. Selain yang berkepentingan, yaitu seperti pekerja, supervisor, dan manager, tidak diperbolehkan memasuki area site proyek. Hal ini untuk meminimalisir kontaminasi dengan orang luar. Siapapun yang masuk dalam kategori berikut, tidak diizinkan masuk site konnstruksi, sebagai berikut :

- Ada anggota keluarga atau kerabat dekat yang sedang karantina atau positif Covid-19.

- Menunjukkan satu atau lebih gejala Covid-19

- Orang yang rentan (faktor usia, kondisi klinis, hamil)

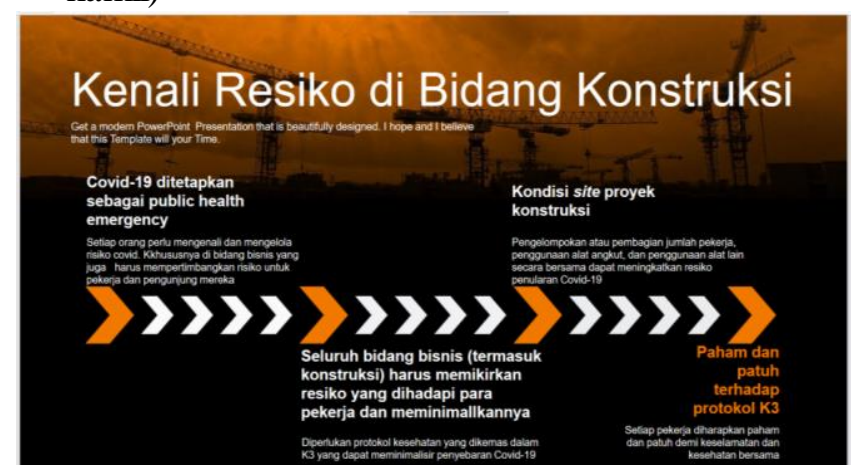

Gambar 2. Resiko Paparan Terhadap Virus Corona di Bidang Konstruksi.

\section{Alat Pelindung Diri (APD) di Site Kons truksi Bebagai alat pelindung diri yang wajib dikenakan guna meminimalis ir penyebaran Covid-19 di site.}




\section{Gunakan Masker}

Penggunaan masker dimaksudkan untuk menutupi area hidung dan mulut untuk menghindari penularan melalui droplet atau tetesan air serta transmisi udara. Bukti menunjukkan bahwa memakai penutup wajah tidak melindungi anda, tetapi mungkin melindungi orang lain jika anda terinfeksi tetapi belum menunjukkan gejala.

Masker yang digunakan adalah bukan masker medis/masker bedah dan memiliki ketentuan :

- Apabila menggunakan jenis reusable mask atau masker dengan material dapat dicuci, maka sediakan 2 masker atau lebih dan cucilah secara teratur.

- Ganti masker setiap hari

- Ketika sedang menggunakan masker, hindari menyentuh area wajah dan masker karena dapat mengontaminasi area tersebut dengan tangan anda.

- Dan apabila tersentuh tangan, maka gantilah masker anda atau jika itu disposable mask maka segera buang.

\section{Gunakan Sarung Tangan}

Sarung tangan yang digunakan adalah bukan sarung tangan medis/sarung tangan bedah. Penggunaan sarung tangan dapat meminimalis ir penularan melalui transmisi fomiten yaitu virus yang terdapat di permukaan benda seperti di alat-alat yang dipakai bekerja terlebih apabila alat tersebut setelah dipakai pekerja lain dan belum di desinfektan.

\section{Gunakan Pelindung Mata}

Penggunaan pelindung mata juga meminimalis ir penularan melalui droplet atau tetesan air.

\section{Gunakan Wearpack}

Penggunaan wearpack atau baju safety lapangan sangat dianjurkan agar apabila terjadi transmisi fomite yang mengenai permukaan pakaian yang dipakai, virus tidak terbawa sampai ke tempat tinggal karena setelah pekerjaan selesai, pekerja lapangan dianjurkan untuk berganti pakaian.

Wearpack sangat beragam jenis dan model nya, sesuaikan dengan yang biasa dipakai oleh perusahaan masing-masing, yang high visibility tentunya lebih bagus karena lebih memberikan keselamatan dalam bekerja.

\section{Gunakan Safe ty footwear}

Seperti yang banyak diketahui, baik transmisi droplet ataupun fomite banyak ditemukan di lantai. Sepatu, selain melindungi dari alat-alat yang mungkin terjatuh atau mengenai kaki, sepatu juga melindungi kaki dari transmisi virus yang berada di lantai terlebih sepatu proyek sangat tertutup dan melindungi kaki secara keseluruhan.

\section{Gunakan Helm Proyek}

Bagian tubuh yang sering tersentuh oleh tangan selain bagian wajah (mata, hidung, mulut) adalah rambut. Untuk menghindari tangan yang mungkin telah terkontaminasi, penggunaan helm dapat meminimalisir area rambut yang mungkin sering tersentuh oleh tangan.

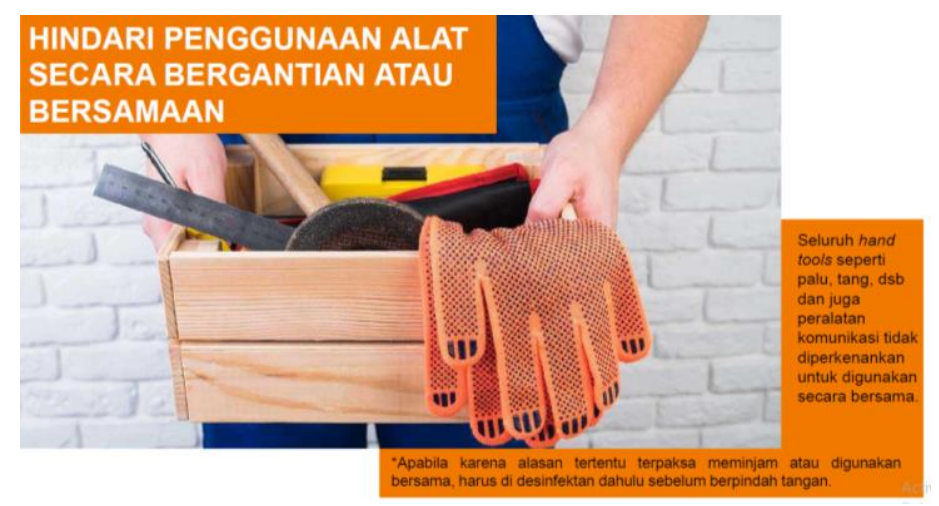

Gambar 3. Penggunaan APD di site konstruksi tidak boleh dipakai bersama (personal use).

\section{Protokol K3 Anti-Covid 19 di Site Konstruksi}

Peraturan-peraturan yang harus dipatuhi ketika pekerja memasuki dan memulai bekerja di site meliputi tiga tahapan berikut ini :

1. Ketika akan memasuki site proyek

- Kendaraan Pengangkut

Membatasi Jumlah Penumpang Kendaraan Pengangkut Pekerja Ke Site Proyek. Apabila ada kendaraan yang mengangkut pekerja ke site, seperti minibus, van, atau kendaraan lainnya, batasi jumlah penumpang yang diangkut hingga $50 \%$ dan terapkan physical distancing dengan jarak minimal 1 meter.

\section{- Pengaturan Antrean}

Pengaturan bergilir ketika memasuki site untuk menghindari kerumunan. Untuk menghindari penumpukan pekerja ketika jam masuk kerja dan akan memasuki site, harus dibuat pengaturan secara bergilir atau dengan penambahan jalur pintu masuk dan dengan antrian yang berjarak 1 hingga 2 meter antar pekerja yang akan masuk dan alurnya adalah one way.

\section{- Pengecekan Suhu Tubuh}

Siapapun yang akan masuk ke site, harus melalui pengecekan suhu tubuh dimanayang tidak memenuhi persyaratan, tidak diperbolehkan masuk. Pengecekan suhu tubuh dilakukan dengan menggunakan thermo gun dengan tidak menyentuh bagian tubuh masing-masing. Pengecekan suhu tubuh ini dilakukan sebagai screening awal terhadap salah satu gejala Covid-19 


\section{- Mencuci Tangan}

Sebelum memasuki area site, diwajibkan untuk cuci tangan dengan air dan sabun atau hand sanitizer. Basahi tangan dengan air dan aplikasikan sabun. Bersihkan seluruh bagian tangan sampai ke selasela hingga minimum 20 detik. Setelah itu bilas dengan air bersih yang mengalir. Apabila tidak ada air dan sabun, bisa menggunakan handsanitizer dengan kandungan alkohol minimum 60\%. Dan akan sangat bagus lagi jika terdapat desinfectan chamber di pintu masuk.

2. Ketika didalam site proyek

Mencakup peraturan-peraturan yang harus dilaksanakan pada saat berada dalam site konstruksi.

- Penyemprotan ke Seluruh Area

Sebelum semua pekerjaan dimulai tiap harinya, dilakukan penyemprotan desinfektan ke seluruh area dan peralatan. Mensterilisasi seluruh area dan peralatan sebelum digunakan

- Desinfektan peralatan

Sebelum semua pekerjaan dimulai tiap harinya, dilakukan penyemprotan desinfektan ke seluruh area dan peralatan mensterilisasi seluruh area dan peralatan sebelum digunakan

- Zona kerja

Memisahkan lokasi menjadi zona kerja agar kelompok pekerja yang berbeda terpisah secara fis ik. Pengelompokan pekerja berdasarkan alokasi tugas dan zona kerja, seperti yang telah disinggung di awal, dilakukan pengurangan personil dan benarbenar dibutuhkan saja serta dilakukan shifting untuk menghindari kerumunan di satu zona dalam jumlah yang besar.

- Mengurangi banyaknya pergerakan

Mengurangi banyaknya pergerakan di banyak area atau zona. Mengurangi pergerakan dilintas zona. Keperluan-keperluan penting seperti pengecekan, memastikan sesuatu, atau dan lain sebagainya bisa dilakukan dengan menggunakan teknologi atau komunikasi elektronik seperti telepon atau handy talky.

- Mengurangi Rotasi Pekerja

Mengurangi rotasi pekerja berarti mengurangi rotasi atau penggunaan alat (alat akan dibahas pada bahasan APD). Jadi sebaiknya menerapkan 1 pekerjan per 1 hari (single task for the day)

- Physical distancing

Menerapkan physical distancing dan memasang signage sebagai pengingat Penanda atau petunjuk untuk tetap physical distancing dengan jarak 1-2 meter sepanjang hari sangat penting sebagai pengingat tiap pekerja. Apabila ada satu dan lain hal yang tidak memungkinkan untuk dilakukan physical distancing, maka :
- Tingkatkan frekuensi mencuci tangan dan membersihkan permukaan benda

- Sebisa mungkin mempersingkat aktivitas untuk mempersingkat durasi dan resiko terpapar.

- Menggunakan metode back-to-back atau side-toside antar pekerja (hindari face-to-face).

- Penanda jarak aman antrian

Di area-area tertentu yang memungkinkan terjadi antrian, diberi penanda jarak aman 1-2 meter antar antrian di bagian bawah atau railing. Penanda dimaksudkan agar selalu tertib dalam antrian yang berjarak 1-2 meter

3. Ketika meninggalkan site proyek

Mencakup peraturan-peraturan yang harus dilaksanakan setelah jam kerja selesai dan hendak meninggalkan site.

- Pembersihan Area Kerja Masing-Masing

Pembersihan seluruh area kerja oleh pekerja berdasarkan penempatan zona masing-masing Sebelum meninggalkan area site, seluruh pekerja diwajibkan membersihkan area kerja masingmasing berdasarkan penempatan zona. Fokusnya adalah untuk mensterilisasi kembali area yang telah dipakai bekerja guna mengurangi resiko penularan melalui seseorang yang menyentuh permukaan yang terinfeksi. Dan prioritas pembersihan diberikan kepada permukaan dengan lalu lintas tinggi dalam hal kontak dengan tangan.

- Pembersihan Hand Tools Pribadi

Pembersihan alat-alat tangan yang digunakan pribadi dengan tujuan apabila keesokan harinya harus digunakan atau dipinjamkan ke pekerja lain.

- Melepas wearpack

Sebelum Meninggalkan Site, me lepaskan wearpack yang telah digunakan seharian untuk meminimalisir kontaminasi atau transmisi fomite virus di pakaian agar tidak terbawa pulang ke tempat tinggal masing-masing.

\section{KESIMPULAN}

Di Indonesia, kemampuan masyarakat memahami bagaimana penanganan pandemi Covid-19 dinilai sangat rendah. Konsep keselamatan dan kesehatan kerja (K3) yang merupakan salah satu aspek perlindungan ketenagakerjaan dan merupakan hak dasar dari setiap tenaga kerja sering kali diabaikan oleh perusahaan konstruksi. Berdasarkan hasil riset pada pekerja konstruksi, tingkat pendidikan pekerja konstr uksi di Surabaya tergolong rendah sehingga sosialisasi dan edukasi dari pihak perusahaan merupakan kunci utama dislipin K3 dilakukan dalam kegiatan bekerja dalam kondisi wabah Covid-19 ini. Siapapun yang masuk dalam kategori berikut, tidak diizinkan masuk site konstruksi, antara lain bila ada anggota keluarga atau kerabat dekat yang sedang karantina atau positif Covid-19, 
menunjukkan satu atau lebih gejala Covid-19, dan orang yang rentan (faktor usia, kondisi klinis, hamil). Alat Pelindung Diri (APD) yang harus digunakan dalam site konstruksi antara lain masker, sarung tangan, pelindung mata, wearpack, safety footwear dan helm proyek. Peraturan-peraturan yang harus dipatuhi ketika pekerja memasuki dan memulai bekerja di site meliputi tiga tahapan berikut ini :

- Ketika akan memasuki site proyek

- Ketika di dalam site proyek

- Ketika meninggalkan site proyek

\section{REFERENSI}

Brawijaya. 2018. Keselamatan Kerja Konstruksi, Workshop Pengembangan Keprofesian Berkelanjutan Tenaga Ahli Bidang K3 Konstruksi, September 2018, Dirjen Bina Konstruksi, Kementrian PUPR, ACEH.

Endriastuty dan Adawia. 2018. "Analisa Hubungan Antara Tingkat Pendidikan, Pengetahuan Tentang K3 Terhadap Budaya K3 Pada Perusahaan Manufaktur”, Jurnal Ecodemica: Jurnal Ekonomi, Manajemen, dan Bisnis. Vol. 2 Jilid. 2.

Hilda B Alexander. 2018. Penting, Implementasi K3 di Seluruh Proyek Konstruksi, diakses pada tanggal $21 \quad$ Mei 2020 melalui <https://properti.kompas.com>
Instruksi Menteri Pekerjaan Umum dan Perumahan Rakyat No. 02/In/M/2020 tentang Protokol Pencegahan Penyebararan Corona Virus Desease 2019 (Covid-19) Dalam Penyelenggaraan Jasa Konstruksi.

Lazuardi Nurdin. 2020. Implementasi K3 di Sektor Konstruksi dalam Pandemi Covis-19, Seminar Nasional (Online), Webinar 18 Mei 2020, Fakultas Teknik, UISU, Medan.

Parinduri, Luthfi dan Taufik Parinduri. 2020. " Implementasi Manajemen Keselamatan Konstruksi Dalam Pandemi Covid 19. Buletin Utama Teknik Vol. 15, No. 3, Mei 2020. ISSN : 2598-3814 (Online), ISSN : 1410-4520.

----. 2020i (1 April). Laporan situasi penyakit virus corona 2019 (COVID-19) - 72. Organisasi Kesehatan dunia. Tersedia di: https://www.who.int/docs/defaultsource/coronaviruse/situationreports/20200401-sitrep-72-COVID19.pdf?sfvrsn=3dd8971b_2

---. UU No. 2 Tahun 2017 tentang Jasa Konstruksi ----. 2020, Covid -19 dan Dunia Kerja : Dampak dan Tanggapan, Departemen Standard Ketenagakerjaan Internasional, ILO

----. 2020, Dalam Menghadapi Pandemi : Memastikan Keselamatan dan Kesehatan di Tempat Kerja, Labour Administration, Labor Inspection and Occupational Safety and Health Branch (LABADMIN/OSH) ILO, Geneva, Switzerland. 